\title{
ANALISIS KUALITAS LAYANAN DAN KEPUASAN PELANGGAN PADA JARINGAN GAS BUMI RUMAH TANGGA
}

\author{
Hayu Kartika \\ Program Studi Teknik Industri, Universitas Mercu Buana \\ e-mail: hayu_kartika@yahoo.com
}

\begin{abstract}
ABSTRAK
Pemakaian gas sebagai suatu energi alternatif merupakan suatu hal yang sangat beralasan, mengingat cadangan gas alam yang dimiliki Indonesia masih sangat besar. Sehingga membuat pemerintah bersama pemerintah daerah saling bekerjasama dalam mensukseskan konversi bahan bakar minyak ke gas bumi. Pemerintah daerah mempunyai wewenang untuk melakukan pengelolaan jaringan gas bumi rumah tangga di daerahnya. Penelitian ini membahas tentang kualitas layanan, dengan menggunkan metode Service Quality (SERVQUAL) dimaksudkan untuk mengetahui gap antara persepsi dan harapan pelanggan jaringan gas bumi. Penelitian dilakukan kepada 100 responden, hasil yang didapat dalam penelitian ini yaitu: bahwa kinerja pelayanan jaringan gas bumi masih belum sesuai dengan yang diharapkan pelanggan sehingga pelanggan masih belum puas dilihat dari rata-rata hasil gap skor SERVQUAL sebesar -1,18. Dari hasil tersebut yang menjadi prioritas perbaikan ada 7 atribut dari dimensi SERVQUAL. Hasil ini diperoleh dengan metode Importance Performance Analysis (IPA) dan dipetakan ke dalam suatu diagram kartesius. Hal tersebut menjadi perhatian pengelola dan pemerintah agar membentuk strategi untuk perbaikan kinerjanya.
\end{abstract}

Kata Kunci : Kualitas Layanan, Kepuasan Pelanggan, Jaringan Gas, Importance Performance Quality

\begin{abstract}
The use of gas as an alternative energy is something that is very reasonable, considering the natural gas reserves in Indonesia is still very large. Thus making the government and the local authorities together for the success of the conversion of fuel oil to natural gas. The local government has the authority to take over the management of the domestic natural gas network area.This research will discuss about the quality of service, using the Service Quality (SERVQUAL) to determine the gap between customer perceptions and expectations of network gas. This research was conducted to 100 respondents, the results obtained in this research were: that the natural gas network service performance is still not in accordance with customer expectations so that the customer is still not satisfied, seen from the average yield gap SERVQUAL score of -1.18. From these results, there are 7 attributes that priority improvement of SERVQUAL dimensions. These results were obtained by the method of Importance Performance Analysis (IPA) and mapped into a Cartesian diagram. It is of concern to the management and the government to establish a strategy for performance improvement
\end{abstract}

Keywords: Service Quality, Customer Satisfaction, Gas Networks, Importance Performance Quality

\section{PENDAHULUAN}

Proyek pengelolaan distribusi gas bumi untuk rumah tangga telah dimulai Juni 2011 oleh Pemerintah Kota Depok. PT Jabar Energi sebagai Badan Usaha Milik Daerah (BUMD) adalah Perusahaan energi yang didirikan untuk mengelola potensi Jawa Barat di bidang migas, panas bumi, dan energi terkait secara efisien dan ramah lingkungan untuk meningkatkan kesejahteraan masyarakat Jawa Barat pada Juni 2011 ditunjuk sebagai perusahaan untuk mengelola sistem jaringan gas di kota Depok. Menyediakan pelayanan dan bermutu tinggi menjadi tugas utama, keharusan untuk senantiasa mengutamakan kepuasan pelanggan. Pihak manajemen harus sadar akan tingginya sistem kualitas pelayanan menjadi fokus utama karena desakan dan harapan dari masyarakat untuk pemerintah daerah memberikan layanan kepada mereka dengan standart kualitas seperti yang diharapkan. Namun, memberikan kualitas tinggi dan hemat biaya bukanlah pekerjaan mudah, itu melibatkan organisasi dengan pendekatan yang tepat, menetapkan cara jelas tentang bagaimana memberikan layanan dan menempatkan orang yang tepat ditempat untuk merespons kebutuhan warga.

Setelah Juni 2011 lalu jaringan gas kota di Depok resmi dijalankan namun sampai saat ini belum diketahui bagaimana tingkat kepuasaan pelanggan pengguna jaringan gas kota tersebut, dan bagaimana kualitas layanan dari pihak 
pengelola jaringan gas kota terhadap para pelanggannya. Oleh sebab itu pengelola jaringan gas kota yaitu PT. Jabar Energi seharusnya mengevaluasi kualitas layanan mereka, dan juga menerima masukan dan saran dari pelanggannya tentang kualitas layanan yang telah diberikan kepada pelanggan apakah sudah memberikan pelayanan yang baik sehingga pelanggan merasa puas dan tidak berfikir negatif terhadap pihak pengelola.

\section{TINJAUAN PUSTAKA}

\section{Kualitas Jasa}

Kualitas berkaitan erat dengan kepuasan pelanggan. Kualitas memberikan dorongan khusus bagi pelanggan untuk menjalin ikatan relasi saling menguntungkan dalam jangka panjang dengan perusahaan. Ikatan emosional semacam ini memungkinkan perusahaan untuk memahami dengan seksama harapan dan kebutuhan spesifik pelanggan. Ada banyak sekali definisi dan pengertian kualitas. Pengertian kualitas menurut Evan dan Lindsay dari beberapa ahli antara lain [1]:

- Kualitas menurut Juran adalah kesesuaian dalam pemanfaatan dan pemakaiannya (fitness for use)".

- Kualitas menurut Crosby adalah conformance to requirement, yaitu sesuai dengan yang disyaratkan atau distandarkan”. Suatu produk memiliki kualitas apabila sesuai dengan standar kualitas yang telah ditentukan agar tidak terjadi kesalahan (Zero deffect)".

- Menurut Deming "Kualitas harus bertujuan memenuhi kebutuhan pasar atau pelanggan sekarang dan di masa yang akan datang”.

- Menurut Feigenbaum "Kualitas merupakan keseluruhan karakteristik produk dan jasa yang meliputi marketing, engineering, manufacture, dan maintenance, dalam mana produk dan jasa tersebut dalam pemakaiannya akan sesuai dengan kebutuhan dan harapan pelanggan”.

\section{Model Service Quality (SERVQUAL)}

Model kualitas jasa yang paling popular dan hingga kini banyak dijadikan acuan dalam riset dan kepuasan pelanggan adalah model SERVQUAL (service quality) [2]. Model yang dikenal pula dengan istilah Gap Analysis Model. Rancangan ini menegaskan bahwa bila kinerja pada suatu atribut (attribute performance) meningkat lebih besar dari pada harapan (expectation) atas atribut bersangkutan, maka persepsi terhadap kualitas dan jasa akan positif dan sebaliknya.

Secara rinci ada lima gap kualitas jasa yang berpotensi menjadi sumber masalah kualitas jasa. Model ini dikembangkan dengan maksud untuk membantu dalam menganalisis sumber masalah kualitas dan memahami caracara memperbaiki kualitas jasa. Model ini diilustrasikan pada gambar, garis putus-putus horizontal memisahkan dua fenomena utama, yaitu bagian atas merupakan fenomena yang berkaitan dengan pelanggan, dan bagian bawah mengacu pada fenomena pada perusahaan.

\section{METODE PENELITIAN}

Subjek penelitian ini adalah Penggunaan Jaringan Gas Bumi Rumah Tangga-Beiji, Depok, sedangkan objek penelitian ini adalah perbaikan layanan terhadap kepuasan pelanggan pengguna jaringan gas bumi di Beiji, Depok (Gambar 2).

\section{HASIL DAN PEMBAHASAN.}

\section{Karakteristik Responden}

Penelitian ini menggunakan tabel yang menyajikan suatu hasil dari 100 kuesioner yang disebar kepada responden untuk mengetahui perbedaan karakteristik antara responden yang satu dengan yang lainnya. Perbedaan tersebut meliputi usia, jenis kelamin, pendidikan, pekerjaan, dan pendapatan dari responden. Data responden yang terkumpul dapat terlihat pada Tabel 1. 


\section{Customer}

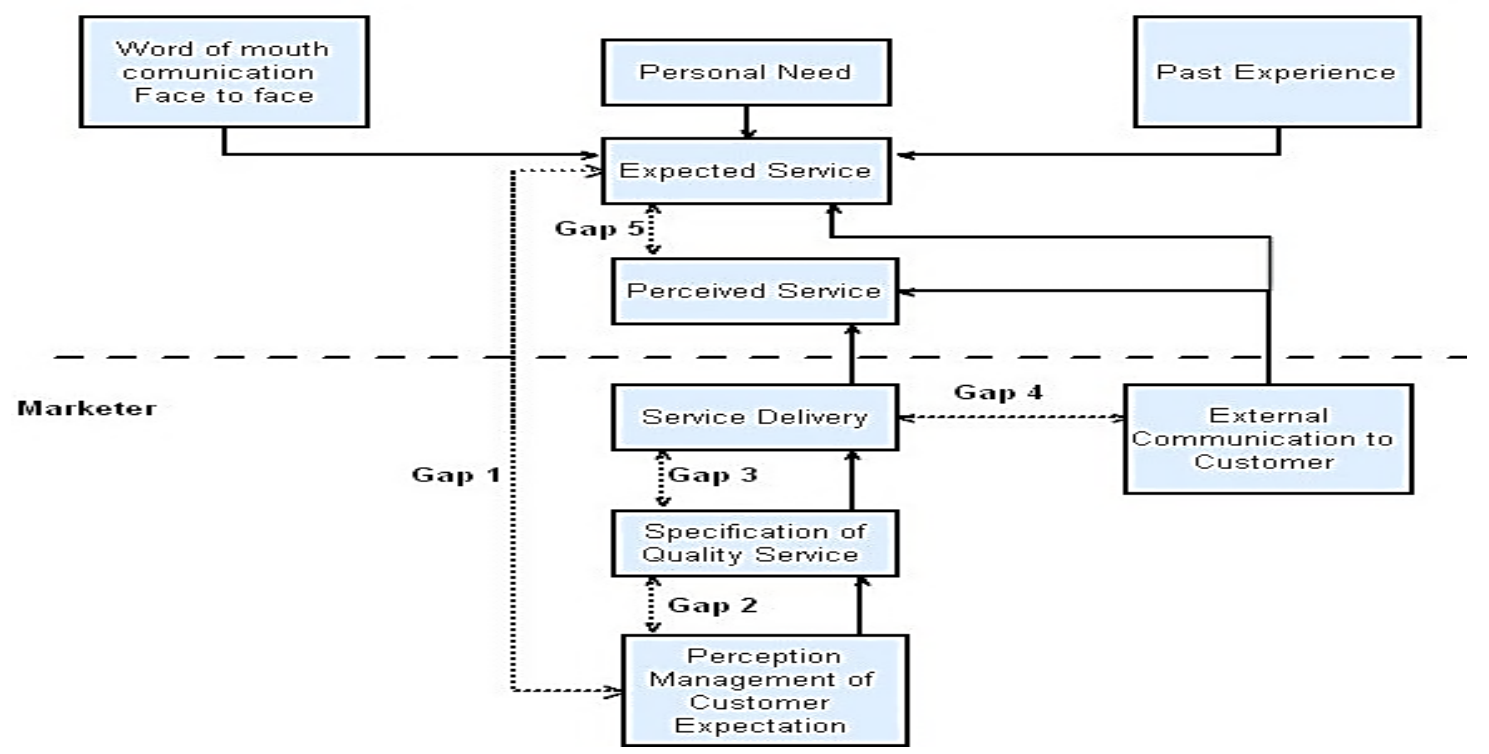

Gambar1. Model Kualitas Jasa (Gap Model) [3]

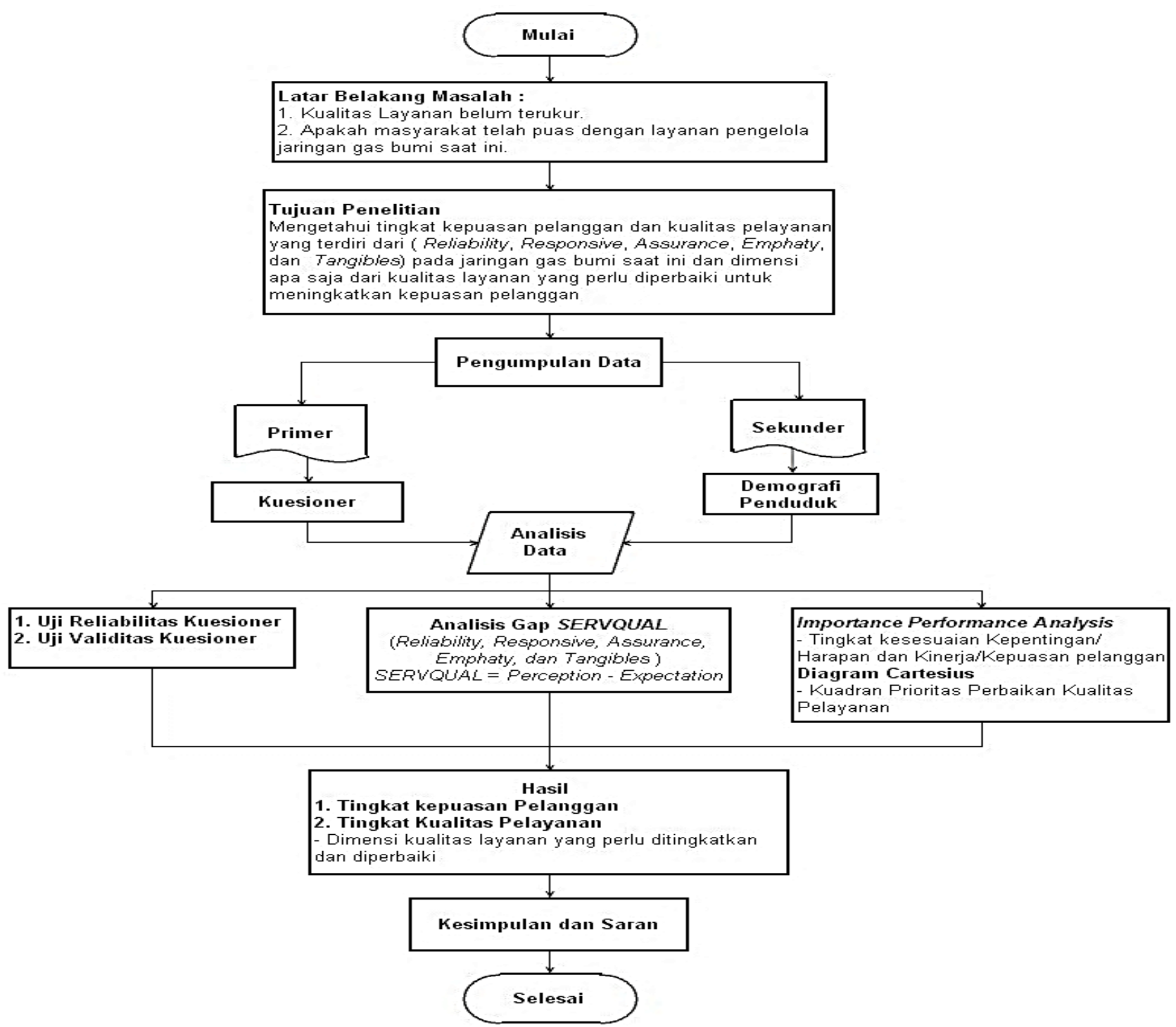

Gambar2. Flow Chart Penelitian 
Tabel 1. Data Responden Berdasarkan Pekerjaan dan Pendapatan

\begin{tabular}{ccccc}
\hline Identitas Responden & \multicolumn{2}{c}{ Jenis Kelamin } & \multicolumn{2}{c}{$\begin{array}{c}\text { Presentase } \\
\%\end{array}$} \\
\hline Pekerjaan & Pria & Wanita & Pria & Wanita \\
\hline PNS & 7 & 0 & 10,14 & 0 \\
Pegawai Swasta & 15 & 5 & 21,74 & 16,13 \\
Wiraswasta & 16 & 8 & 23,19 & 25,80 \\
Lain-lain & 31 & 18 & 44,93 & 58,06 \\
\hline Total & 69 & 31 & 100 & 100 \\
\hline Penghasilan & & & & \\
\hline$\leq 1$ jt -3 jt & 38 & 17 & 55,88 & 53,12 \\
3 jt -5 jt & 19 & 11 & 27,94 & 34,38 \\
5 jt -7 jt & 8 & 4 & 11,76 & 12,5 \\
$>7$ jt & 3 & 0 & 4,41 & 0 \\
\hline Total & 68 & 32 & 100 & 100 \\
\hline
\end{tabular}

\section{Pengukuran Kualitas Layanan (SERVQUAL)}

Tabel 2. Tabulasi Data dari Kuesioner

\begin{tabular}{|c|c|c|c|c|c|c|c|c|c|c|c|c|c|c|c|}
\hline \multirow{4}{*}{ Atr } & \multicolumn{7}{|c|}{ Kinerja (Perseptions) } & \multicolumn{7}{|c|}{ Harapan (Expectation) } & Gap \\
\hline & \multicolumn{5}{|c|}{ Frekuensi } & \multirow{3}{*}{ Total } & \multirow{3}{*}{$\mathrm{P}$} & \multicolumn{5}{|c|}{ Frekuensi } & \multirow{3}{*}{ Total } & \multirow{3}{*}{$\mathrm{E}$} & $(\mathrm{P}-\mathrm{E})$ \\
\hline & \multicolumn{5}{|c|}{ Likert } & & & \multicolumn{5}{|c|}{ Likert } & & & \\
\hline & 1 & 2 & 3 & 4 & 5 & & & 1 & 2 & 3 & 4 & 5 & & & \\
\hline R1 & 15 & 25 & 4 & 50 & 6 & 307 & 3,07 & 0 & 0 & 3 & 15 & 82 & 479 & 4,79 & $-1,72$ \\
\hline $\mathrm{R} 2$ & 7 & 33 & 11 & 42 & 7 & 309 & 3,09 & 0 & 0 & 3 & 24 & 73 & 470 & 4,7 & $-1,61$ \\
\hline R3 & 1 & 5 & 14 & 63 & 17 & 390 & 3,9 & 0 & 0 & 3 & 15 & 82 & 479 & 4,79 & $-0,89$ \\
\hline R4 & 3 & 30 & 31 & 35 & 1 & 301 & 3,01 & 0 & 0 & 5 & 18 & 77 & 472 & 4,72 & $-1,71$ \\
\hline R5 & 16 & 29 & 18 & 36 & 1 & 277 & 2,77 & 0 & 0 & 3 & 12 & 85 & 482 & 4,82 & $-2,05$ \\
\hline \multicolumn{15}{|c|}{ Rata-Rata Dimensi Reliability } & $-1,59$ \\
\hline R6 & 12 & 36 & 30 & 20 & 2 & 264 & 2,64 & 0 & 0 & 3 & 25 & 72 & 469 & 4,69 & $-2,05$ \\
\hline R7 & 16 & 25 & 3 & 49 & 7 & 306 & 3,06 & 0 & 0 & 17 & 34 & 49 & 432 & 4,32 & $-1,26$ \\
\hline R8 & 1 & 9 & 23 & 57 & 10 & 366 & 3,66 & 0 & 0 & 5 & 18 & 77 & 472 & 4,72 & $-1,06$ \\
\hline R9 & 13 & 36 & 30 & 19 & 2 & 261 & 2,61 & 0 & 0 & 4 & 25 & 71 & 467 & 4,67 & $-2,06$ \\
\hline \multicolumn{15}{|c|}{ Rata-Rata Dimensi Responsive } & $-1,60$ \\
\hline A10 & 12 & 36 & 30 & 20 & 2 & 264 & 2,64 & 0 & 0 & 25 & 50 & 25 & 400 & 4 & $-0,46$ \\
\hline A11 & 1 & 11 & 39 & 43 & 6 & 342 & 3,42 & 0 & 0 & 4 & 41 & 55 & 451 & 4,51 & $-0,16$ \\
\hline A12 & 7 & 33 & 11 & 42 & 7 & 309 & 3,09 & 0 & 0 & 14 & 38 & 48 & 434 & 4,34 & 0,06 \\
\hline A13 & 1 & 8 & 15 & 61 & 15 & 381 & 3,81 & 0 & 0 & 4 & 41 & 55 & 451 & 4,51 & $-0,7$ \\
\hline \multicolumn{15}{|c|}{ Rata-Rata Dimensi Assurance } & $-0,34$ \\
\hline E14 & 3 & 16 & 19 & 46 & 16 & 356 & 3,56 & 0 & 0 & 16 & 42 & 42 & 426 & 4,26 & $-0,7$ \\
\hline E15 & 2 & 15 & 17 & 54 & 12 & 359 & 3,59 & 0 & 0 & 15 & 51 & 34 & 419 & 4,19 & $-0,6$ \\
\hline E16 & 16 & 25 & 32 & 24 & 3 & 273 & 2,73 & 0 & 0 & 17 & 34 & 49 & 432 & 4,32 & $-1,59$ \\
\hline E17 & 11 & 26 & 21 & 40 & 2 & 296 & 2,96 & 0 & 0 & 12 & 59 & 29 & 417 & 4,17 & $-1,21$ \\
\hline E18 & 13 & 36 & 29 & 20 & 2 & 262 & 2,62 & 0 & 0 & 3 & 61 & 36 & 433 & 4,33 & $\begin{array}{r}-1,71 \\
\end{array}$ \\
\hline \multicolumn{15}{|c|}{ Rata-rata Dimensi Emphaty } & $-1,16$ \\
\hline T19 & 15 & 25 & 4 & 50 & 6 & 307 & 3,07 & 0 & 0 & 25 & 50 & 25 & 400 & 4 & $-0,93$ \\
\hline $\mathrm{T} 20$ & 4 & 45 & 14 & 37 & 0 & 284 & 2,84 & 0 & 0 & 16 & 52 & 32 & 416 & 4,16 & $-1,32$ \\
\hline $\mathrm{T} 21$ & 13 & 36 & 29 & 20 & 2 & 262 & 2,62 & 0 & 0 & 29 & 51 & 20 & 391 & 3,91 & $-1,29$ \\
\hline $\mathrm{T} 22$ & 3 & 30 & 31 & 35 & 1 & 301 & 3,01 & 0 & 0 & 23 & 48 & 29 & 406 & 4,06 & $-1,05$ \\
\hline \multicolumn{15}{|c|}{ Rata-rata Dimensi Tangibles } & $-1,15$ \\
\hline \multicolumn{15}{|c|}{ Rata-rata Keseluruhan SERVQUAL } & $-1,18$ \\
\hline
\end{tabular}

Data-data pengukuran servqual meliputi harapan dan persepsi pelanggan terhadap kinerja pelayanan yang diberikan oleh PT. Jabar Energi. Data didapat dari hasil kuesioner kepada 100 responden pengguna jaringan gas bumi. Dan kemudian penilaian dikelompokkan dalam 5 skala likert dapat dihitung dengan rumus [4]:

Servqual Score $=$ Perception Score Expectation Score

$$
Q=P-E
$$


Berdasarkan hasil data responden pada Tabel 2 dapat terlihat bahwa skor akhir yang dihasilkan oleh gap antara persepsi pelanggan dengan ekspektasi pelanggan menunjukkan hasil keseluruhan rata-rata bernilai negatif yaitu -1.18 seperti pada Gambar 3.

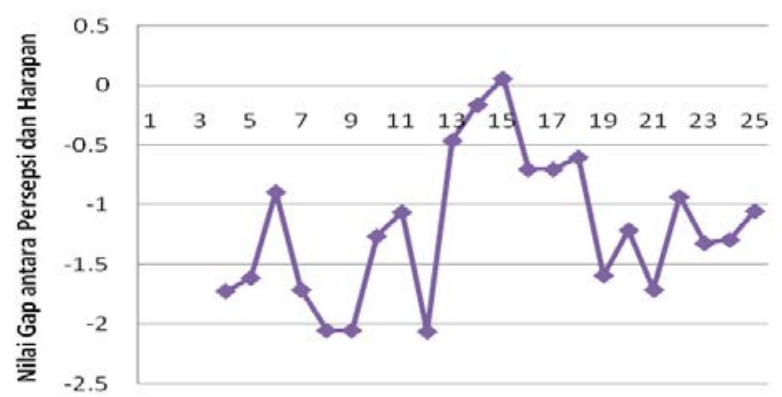

Gambar 3. Gap Servqual Antara Persepsi dan Harapan

Berdasarkan Gambar 3 dapat diartikan kinerja pelayanan jaringan gas bumi masih jauh dari harapan pelanggan, dapat disimpulkan pelanggan saat ini masih belum merasa puas, pelanggan ingin mendapatkan pelayanan yang lebih baik lagi.

\section{Importance Performance Analysis (IPA)}

Analisis dengan Importance Performance Analysis ini dilakukan untuk mengetahui urutan prioritas atribut-atribut dari dimensi kualitas yang menjadi prioritas perbaikan yang dinilai berdasarkan presentase perbandingan nilai kinerja dengan tingkat kepentingan/harapan menurut penilaian dari responden, tingkat kesesuaian/kepuasan pelanggan (customer satisfaction) diukur dalam kaitannya dengan apa yang seharusnya dikerjakan oleh perusahaan apakah sudah sesuai kualitas pelayanan yang telah diberikan kepada pelanggan dan apakah sudah terdapat kepuasan terhadap para pelanggan.

\section{Pengukuran Kualitas Layanan dengan Importance Performance Analysis (IPA) 1. Dimensi Reliability}

Berdasarkan jawaban responden atas pertanyaan mengenai dimensi reliability ini untuk mengetahui sejauhmana tingkat kinerja pengelola jaringan gas bumi dan harapan pelanggannya.

Berdasarkan dari hasil perhitungan tingkat harapan dan kinerja jaringan gas bumi dari 100 responden atas dimensi reliability yang disajikan dalam Tabel 3, maka tingkat kesesuaian/kepuasan pelanggan dapat ditentukan sebagai berikut :

$$
T k i=\frac{X_{i}}{Y_{i}} \times 100 \%=\frac{1584}{2382} \times 100 \%=66,50 \%
$$

Tingkat tingkat kesesuaian/kepuasan pelanggan pada dimensi reliability adalah sebasar 66,50\%, Jumlah skor kriterium untuk dimensi ini yaitu (untuk ini skor tertinggi $=5$, jumlah item $=5$, dan jumlah responden $=100$ ) maka skor kriterium $=5 \times 5 \times 100=2500$. Hal ini secara kontinum dapat dibuat kategori seperti Gambar 4.

Dari Gambar 4 menunjukkan bahwa kinerja pengelola masih jauh dari harapan

Tabel 3. Tingkat Kesesuaian/Kepuasan Pelanggan pada Dimensi Reliability

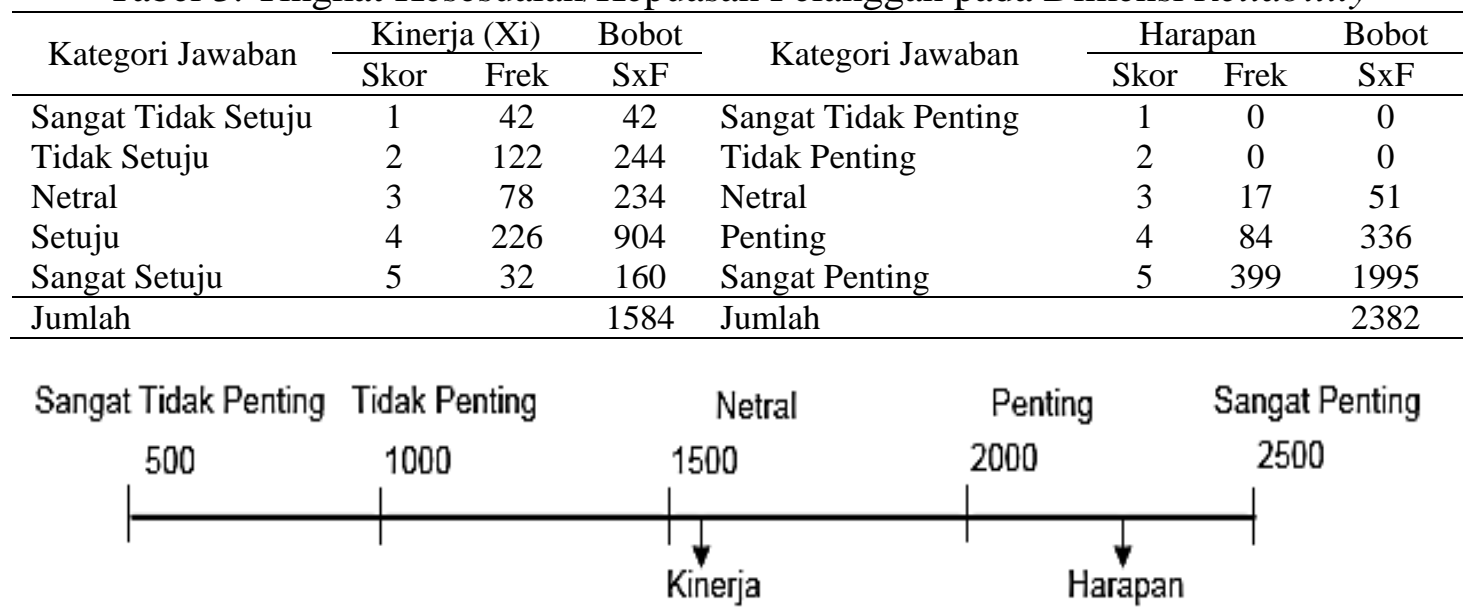

Gambar 4. Tingkat Kepuasan Pelanggan Dimensi Reliability secara Kontinium 
Tabel 4. Tingkat Kepuasan Pelanggan pada Dimensi Responsive

\begin{tabular}{lcccccccc}
\hline \multirow{2}{*}{ Kategori Jawaban } & \multicolumn{2}{c}{ Kinerja $(\mathrm{Xi})$} & \multicolumn{2}{c}{ Bobot } & \multirow{2}{*}{ Kategori Jawaban } & \multicolumn{2}{c}{ Harapan } & \multicolumn{2}{c}{ Bobot } \\
\cline { 2 - 4 } & Skor & Frek & SxF & & Skor & Frek & SxF \\
\hline Sangat Tidak Setuju & 1 & 42 & 42 & Sangat Tidak Penting & 1 & 0 & 0 \\
Tidak Setuju & 2 & 106 & 212 & Tidak Penting & 2 & 0 & 0 \\
Netral & 3 & 86 & 258 & Netral & 3 & 29 & 87 \\
Setuju & 4 & 145 & 580 & Penting & 4 & 102 & 408 \\
Sangat Setuju & 5 & 21 & 105 & Sangat Penting & 5 & 269 & 1345 \\
\hline Jumlah & & & 1197 & Jumlah & & & 2382 \\
\hline
\end{tabular}

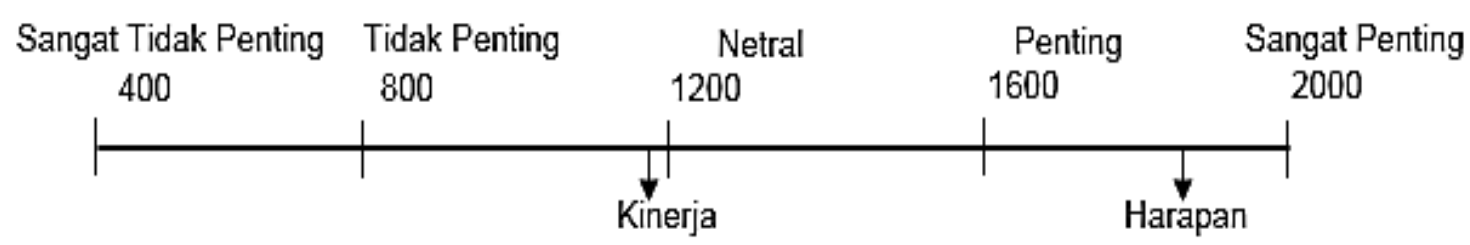

Gambar 5. Tingkat Kepuasan Pelanggan Dimensi Responsive secara Kontinium

Tabel 5. Tingkat Kepuasan Pelanggan pada Dimensi Assurance

\begin{tabular}{lccclcccc}
\hline \multirow{2}{*}{ Kategori Jawaban } & \multicolumn{2}{c}{ Kinerja $(\mathrm{Xi})$} & Bobot & \multirow{2}{*}{ Kategori Jawaban } & & \multicolumn{2}{c}{ Harapan } & Bobot \\
\cline { 2 - 3 } \cline { 7 - 9 } & Skor & Frek & SxF & & Skor & Frek & SxF \\
\hline Sangat Tidak Setuju & 1 & 21 & 21 & Sangat Tidak Penting & 1 & 0 & 0 \\
Tidak Setuju & 2 & 88 & 176 & Tidak Penting & 2 & 0 & 0 \\
Netral & 3 & 95 & 285 & Netral & 3 & 47 & 141 \\
Setuju & 4 & 166 & 664 & Penting & 4 & 170 & 680 \\
Sangat Setuju & 5 & 30 & 150 & Sangat Penting & 5 & 183 & 915 \\
\hline Jumlah & & & 1296 & Jumlah & & & 1736 \\
\hline
\end{tabular}

pelanggan sehingga dalam dimensi tersebut masih perlu untuk ditingkatkan kinerjanya.

\section{Dimensi Responsive}

Berdasarkan jawaban responden atas pertanyaan mengenai dimensi responsive ini untuk mengetahui sejauhmana tingkat kinerja pengelola jaringan gas bumi dan harapan pelanggannya.

Berdasarkan dari hasil perhitungan tingkat harapan dan kinerja jaringan gas bumi dari 100 responden atas dimensi responsive yang disajikan dalam Tabel 4, maka tingkat kesesuaian/kepuasan pelanggan dapat ditentukan sebagai berikut :

$$
T k i=\frac{X_{i}}{Y_{i}} \times 100 \%=\frac{1197}{184} \times 100 \%=65,05 \%
$$

Tingkat kesesuaian/kepuasan pelanggan pada dimensi responsive adalah sebasar 65,05\%, Jumlah skor kriterium untuk dimensi ini yaitu (untuk ini skor tertinggi $=5$, jumlah item $=4$, dan jumlah responden $=100$ ) maka skor kriterium $=5 \times 4 \times 100=2000$. Hal ini secara kontinum dapat dibuat kategori seperti pada Gambar 5.

Dari Gambar 5 menunjukkan bahwa kinerja pengelola masih jauh dari harapan pelanggan sehingga dalam dimensi tersebut masih perlu untuk ditingkatkan kinerjanya.

\section{Dimensi Assurance}

Berdasarkan jawaban responden atas pertanyaan mengenai dimensi Assurance ini untuk mengetahui sejauhmana tingkat kinerja pengelola jaringan gas bumi dan harapan pelanggannya.

Berdasarkan dari hasil perhitungan tingkat harapan dan kinerja jaringan gas bumi dari 100 responden atas dimensi assurance yang disajikan dalam Tabel 5, maka tingkat kesesuaian/kepuasan pelanggan dapat ditentukan sebagai berikut :

$$
T k i=\frac{X_{i}}{Y_{i}} \times 100 \%=\frac{1296}{1736} \times 100 \%=74,65 \%
$$

Tingkat kesesuaian/kepuasan pelanggan pada dimensi assurance adalah sebasar 74,65\%, Jumlah skor kriterium untuk dimensi ini yaitu 


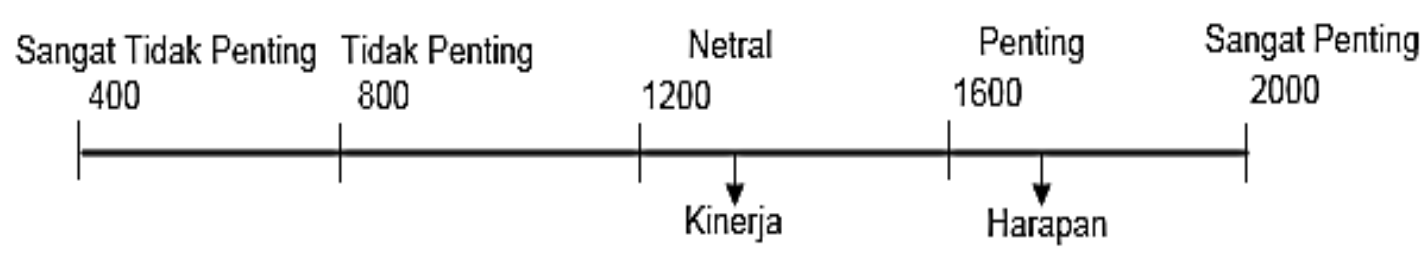

Gambar 6. Tingkat Kepuasan Pelanggan Dimensi Assurance secara Kontinium

Tabel 6. Tingkat Kepuasan Pelanggan pada Dimensi Emphaty

\begin{tabular}{|c|c|c|c|c|c|c|c|}
\hline \multirow{2}{*}{ Kategori Jawaban } & \multicolumn{2}{|c|}{ Kinerja (Xi) } & \multirow{2}{*}{$\frac{\text { Bobot }}{\text { SxF }}$} & \multirow{2}{*}{ Kategori Jawaban } & \multicolumn{2}{|c|}{ Harapan } & \multirow{2}{*}{$\frac{\text { Bobot }}{\text { SxF }}$} \\
\hline & Skor & Frek & & & Skor & Frek & \\
\hline Sangat Tidak Setuju & 1 & 45 & 45 & Sangat Tidak Penting & 1 & 0 & 0 \\
\hline Tidak Setuju & 2 & 118 & 236 & Tidak Penting & 2 & 0 & 0 \\
\hline Netral & 3 & 118 & 354 & Netral & 3 & 47 & 141 \\
\hline Setuju & 4 & 184 & 736 & Penting & 4 & 205 & 820 \\
\hline Sangat Setuju & 5 & 35 & 175 & Sangat Penting & 5 & 148 & 740 \\
\hline Jumlah & & & 1546 & Jumlah & & & 1701 \\
\hline
\end{tabular}

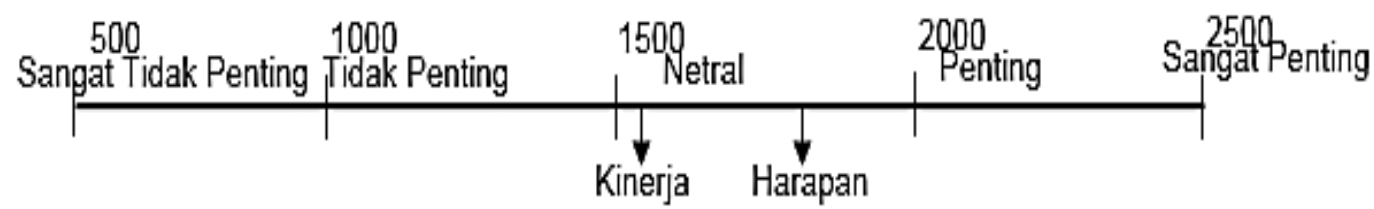

Gambar 7. Tingkat Kepuasan Pelanggan Dimensi Emphaty Secara Kontinium

(untuk ini skor tertinggi $=5$, jumlah item $=4$, dan jumlah responden $=100)$ maka skor kriterium $=5 \times 4$ x 100 $=2000$. Hal ini secara kontinu dapat dibuat kategori seperti ditunjukkan pada Gambar 6.

Dari Gambar 6 menunjukkan bahwa kinerja pengelola untuk meningkatkan kepuasan pelanggan dalam dimensi tersebut masih belum sesuai sehingga perlu ditingkatkan.

\section{Dimensi Emphaty}

Berdasarkan jawaban responden atas pertanyaan mengenai dimensi emphaty ini untuk mengetahui sejauhmana tingkat kinerja pengelola jaringan gas bumi dan harapan pelanggannya.

Berdasarkan dari hasil perhitungan tingkat harapan dan kinerja jaringan gas bumi dari 100 responden atas dimensi emphaty yang disajikan dalam Tabel 6, maka tingkat kesesuaian/ kepuasan pelanggan dapat ditentukan sebagai berikut :

$$
T k i=\frac{X_{i}}{Y_{i}} \times 100 \%=\frac{1546}{1701} \times 100 \%=90,88 \%
$$

Tingkat kesesuaian/kepuasan pelanggan pada dimensi emphaty adalah sebasar 90,88\%,
Jumlah skor kriterium untuk dimensi ini yaitu (untuk ini skor tertinggi $=5$, jumlah item $=5$, dan jumlah responden $=100$ ) maka skor kriterium $=5 \times 5 \times 100=2500$. Hal ini secara kontinum dapat dibuat kategori sebagai berikut.

Dari Gambar 7 menunjukkan bahwa kinerja pengelola sudah mendekati harapan pelanggan tetapi perlu ditingkatkan kembali.

\section{Dimensi Tangibles}

Berdasarkan jawaban responden atas pertanyaan mengenai dimensi tangibles ini untuk mengetahui sejauhmana tingkat kinerja pengelola jaringan gas bumi dan harapan pelanggannya.

Berdasarkan dari hasil perhitungan tingkat harapan dan kinerja jaringan gas bumi dari 100 responden atas dimensi tangibles yang disajikan dalam Tabel 7, maka tingkat kesesuaian/ kepuasan pelanggan dapat ditentukan sebagai berikut :

$$
T k i=\frac{X_{i}}{Y_{i}} \times 100 \%=\frac{1154}{1613} \times 100 \%=71,54 \%
$$

Tingkat kesesuaian/kepuasan pelanggan pada dimensi tangibles adalah sebesar 71,54\%, Jumlah skor kriterium untuk dimensi ini yaitu 
Tabel 7. Tingkat Kepuasan Pelanggan pada Dimensi Tangibles

\begin{tabular}{lcccccccc}
\hline \multirow{2}{*}{ Kategori Jawaban } & \multicolumn{2}{c}{ Kinerja $(\mathrm{Xi})$} & Bobot & \multirow{2}{*}{ Kategori Jawaban } & & \multicolumn{2}{c}{ Harapan } & \multicolumn{2}{c}{ Bobot } \\
\cline { 2 - 4 } & Skor & Frek & SxF & & Skor & Frek & SxF \\
\hline Sangat Tidak Setuju & 1 & 35 & 35 & Sangat Tidak Penting & 1 & 0 & 0 \\
Tidak Setuju & 2 & 136 & 272 & Tidak Penting & 2 & 0 & 0 \\
Netral & 3 & 78 & 234 & Netral & 3 & 93 & 279 \\
Setuju & 4 & 142 & 568 & Penting & 4 & 201 & 804 \\
Sangat Setuju & 5 & 9 & 45 & Sangat Penting & 5 & 106 & 530 \\
\hline Jumlah & & & 1154 & Jumlah & & & 1613 \\
\hline
\end{tabular}

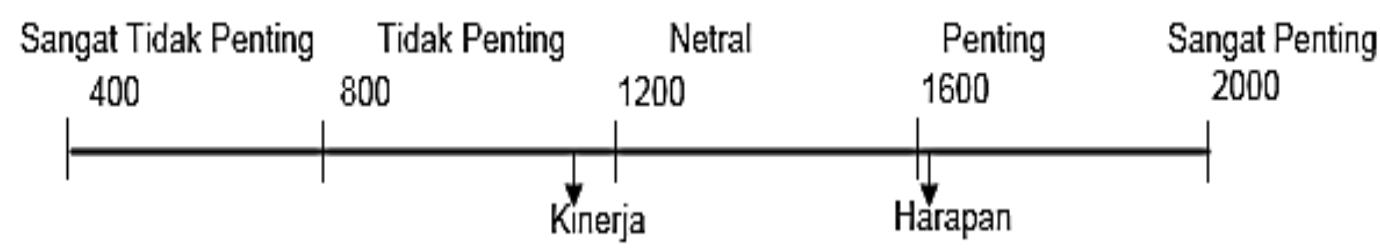

Gambar 8. Tingkat Kepuasan Pelanggan Dimensi Tangibles secara Kontinium

(untuk ini skor tertinggi $=5$, jumlah item $=4$, dan jumlah responden $=100$ ) maka skor kriterium $=5 \times 4 \times 100=2000$. Hal ini secara kontinum dapat dibuat kategori sebagai berikut.

Dari Gambar 8 menunjukkan bahwa kinerja pengelola masih jauh dari harapan pelanggan sehingga dalam dimensi tersebut masih perlu untuk ditingkatkan kinerjanya.

Dari hasil perhitungan dengan tingkat kesesuaian di atas maka dapat dilihat secara menyeluruh masing-masing dari dimensi SERVQUAL sejauhmana tingkat kinerja dengan harapan pelanggan, dalam grafik tersebut akan terlihat dengan jelas tingkat kinerja pengelola jaringan gas bumi saat ini dalam Gambar 9.

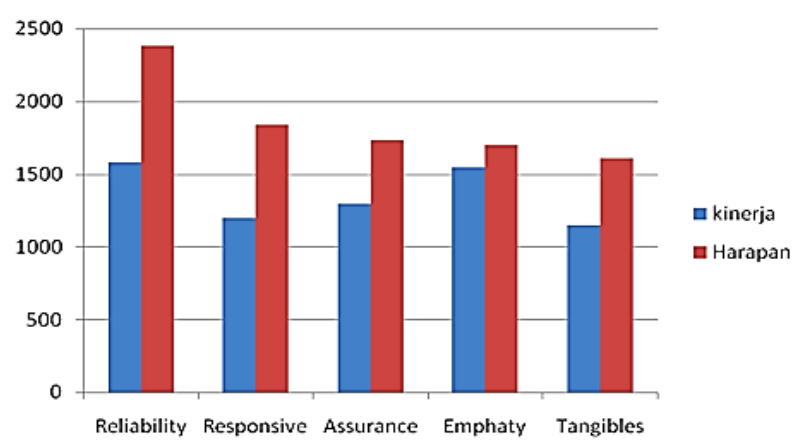

Gambar 9. Rata-rata Tingkat Kepuasan Pelanggan Dimensi SERVQUAL

Berdasarkan grafik pada Gambar 9 dapat dilihat tingkat kinerja pelayanan dari masingmasing dimensi SERVQUAL tersebut. Untuk dimensi Reliability terlihat tingkat kesesuaian kinerja dengan harapan cukup jauh tingkat kinerja pelayanan saat ini sebesar 66,50\%, untuk dimensi Responsive juga telihat tingkat kesesuaian antara kinerja dan harapan masih cukup jauh, kinerja pelayanan saat ini sebesar 65,05\%, untuk dimensi Assurance tingkat kinerja pelayanan saat ini sebesar $74,65 \%$, untuk dimensi Emphaty tingkat kinerja pelayanan saat ini sebesar $90,88 \%$, dimensi ini yang terlihat kinerjanya lebih baik dibandingkan dengan dimensi yang lainnya karena kinerja pelayanan hampir sesuai dengan harapan pelanggan. Untuk dimensi Tangibles kinerja pelayanan saat ini sebesar 71,54\% masih cukup jauh dengan yang pelanggan harapkan. Dari hasil tersebut sudah nampak jelas bahwa kinerja pelayanan jaringan gas bumi masih perlu ditingkatkan kembali dan diperbaiki. Untuk dimensi mana saja yang perlu diprioritaskan untuk perbaikan dan ditingkatkan maka akan ditentukan/dilihat dengan menggunakan kuadran prioritas yaitu Importance Performace matrix.

\section{Importance-Performance Matrix}

Untuk mengetahui tingkat prioritas perbaikan untuk meningkatkan kualitas kinerja pelayanan berdasarkan perhitungan skor dimensi SERVQUAL berdasarkan skor harapan dan skor persepsi masing-masing dimensi beserta rata-rata dari skor rata-rata masingmasing dimensi. Hasil perhitungan tersebut digunakan untuk dapat melihat posisi penempatan data dalam suatu diagram 
Tabel 8. Perhitungan Rata-Rata Penilaian Harapan dan Kinerja Atribut Dimensi SERVQUAL

\begin{tabular}{|c|c|c|c|c|c|c|}
\hline \multirow{2}{*}{ Dimensi } & \multirow{2}{*}{ Atribut } & \multicolumn{2}{|c|}{ Skor } & \multirow{2}{*}{$\bar{X}$} & \multirow{2}{*}{$\bar{Y}$} & \multirow{2}{*}{ TKI (\%) } \\
\hline & & Kinerja (Xi) & Harapan (Yi) & & & \\
\hline \multirow[t]{5}{*}{ Reliability } & R1 & 307 & 479 & 3,07 & 4,79 & 64,09 \\
\hline & $\mathrm{R} 2$ & 309 & 470 & 3,09 & 4,70 & 65,74 \\
\hline & R3 & 390 & 479 & 3,90 & 4,59 & 84,97 \\
\hline & R4 & 301 & 472 & 3,01 & 4,72 & 61,93 \\
\hline & $\mathrm{R} 5$ & 277 & 482 & 2,77 & 4,82 & 57,47 \\
\hline \multirow[t]{4}{*}{ Responsive } & R6 & 264 & 469 & 2,64 & 4,69 & 56,29 \\
\hline & R7 & 306 & 432 & 3,06 & 4,32 & 66,81 \\
\hline & R8 & 366 & 472 & 3,66 & 4,72 & 77,54 \\
\hline & R9 & 261 & 467 & 2,61 & 4,67 & 55,89 \\
\hline \multirow[t]{4}{*}{ Assurance } & A10 & 264 & 400 & 2,64 & 4,00 & 82,33 \\
\hline & A11 & 342 & 451 & 3,42 & 4,51 & 96,45 \\
\hline & A12 & 309 & 434 & 4,09 & 4,34 & 101,38 \\
\hline & A13 & 381 & 451 & 3,81 & 4,51 & 88,60 \\
\hline \multirow[t]{5}{*}{ Emphaty } & E14 & 356 & 426 & 3,56 & 4,26 & 83,57 \\
\hline & E15 & 359 & 419 & 3,59 & 4,19 & 85,68 \\
\hline & E16 & 273 & 432 & 2,73 & 4,32 & 63,19 \\
\hline & E17 & 296 & 417 & 2,96 & 4,17 & 70,98 \\
\hline & E18 & 262 & 433 & 2,62 & 4,33 & 60,51 \\
\hline \multirow[t]{5}{*}{ Tangibles } & T19 & 307 & 400 & 3,07 & 4,00 & 76,75 \\
\hline & $\mathrm{T} 20$ & 284 & 416 & 2,84 & 4,16 & 68,27 \\
\hline & $\mathrm{T} 21$ & 262 & 391 & 2,62 & 3,91 & 67,01 \\
\hline & T22 & 301 & 406 & 3,01 & 4,06 & 74,14 \\
\hline & Rata-rata & & & 3,22 & 44,2 & \\
\hline
\end{tabular}

kartesius. Data yang telah dievaluasi tersebut, maka dapat dibagi menjadi empat bagian, yaitu: Perhitungan nilai rata-rata harapan (Y) dan nilai kinerja (X) dapat dilihat dalam Tabel 8.

Hasil pengukuran atribut di atas memungkinkan pihak PT. Jabar Energi untuk dapat menitikberatkan usaha-usaha perbaikan pada indikator yang benar-benar dianggap penting oleh pelanggan jaringan gas bumi. Untuk melihat titik-titik tersebut, dan prioritas untuk meningkatkan pelayanan dari dimensi SERVQUAL mana saja yang perlu diperbaiki dan mana saja yang tetap dipertahankan agar tidak menurun kualitas pelayanan kepada pelanggan. Untuk itu maka akan ditunjukkan dengan diagram kartesius.

\section{Diagram Kartesius}

Setelah dilakukan perhitungan tingkat kesesuaian terhadap harapan pelanggan dan kinerja jaringan gas bumi atas indikator dimensi SERVQUAL maka nilai-nilai tersebut dapat dipetakan kedalam diagram kartesius pada Gambar 10.

Berdasarkan hasil penelitian yang telah diuraikan di atas maka dapat diketahui urutan prioritas untuk tindakan perbaikanya itu pada Tabel 9.

Dari Tabel 9 dapat dengan mudah melihat prioritas perbaikan kinerja untuk meningkatkan kepuasan pelanggan berdasarkan diagram Importance Performance Analysis. Hasil menunjukkan bahwa pada kuadran I ini merupakan prioritas paling pertama untuk segera dilakukan perbaikan kinerja dimana hasil kinerja masih belum sesuai dengan harapan pelanggan. Pada kuadran ini ada 7 atribut yaitu (R1, R2, R4, R5, R6, R7, dan R9).

Sedangkan pada kuadran II ini ada 3 atribut yaitu (R3, R8, dan A11), bahwa tingkat kinerja telah sesuai dengan tingkat harapan pelanggan sehingga perlu dipertahankan dan jika perlu ditingkatkan kembali. Pada kuadran III ada 7 atribut yaitu (E16, E17, E18, T19, T20, T21, dan T22), pada kuadran ini atribut dinilai masih dianggap kurang penting bagi pelanggan,sedangkan kualitas pelaksanaannya biasa atau cukup.

Selanjutnya atribut yang ada pada kuadran IV yaitu (A10, A12, A13, E14, dan E15). Bahwa bahwa atribut pada kuadran ini dinilai berlebihan dalam pelaksanaannya, sedangkan pelanggan menganggap tidak terlalu 
penting terhadap adanya indikator tersebut, akan tetapi pelaksanaannya dilakukan dengan baik sekali oleh PT. Jabar Energi, sehingga sangat memuaskan.

\section{Prioritas Utama Perbaikan}

Dari Hasil Analisis dan pemetaan dengan kuadran kartesius Importance Performance Analysis maka dapat diketahuivariabel yang menjadi prioritas, dapat dilihat pada Tabel 10.

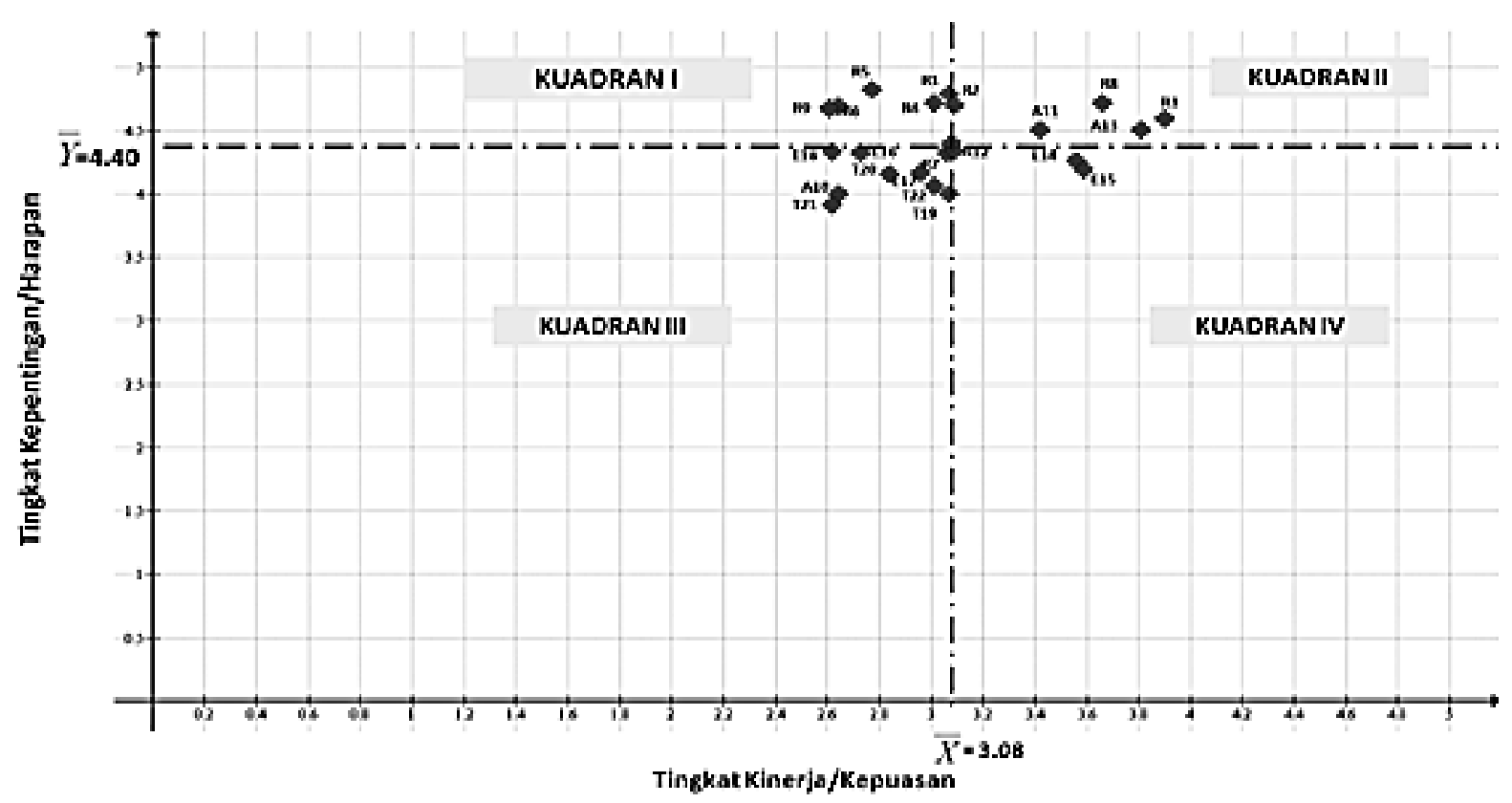

Gambar 10. Diagram Kartesius Importance Performance Matrix

Tabel 9. Urutan Kuadran Prioritas

\begin{tabular}{|c|c|c|c|}
\hline No & & Atribut & $\begin{array}{c}\text { Urutan Prioritas } \\
\text { Kuadran }\end{array}$ \\
\hline 1 & $\mathrm{R} 1$ & Keakuratan catatan yang dilakukan petugas pencatat meter gas & I \\
\hline 2 & $\mathrm{R} 2$ & Penempatan meter gas dilokasi yang sesuai pada tempatnya & I \\
\hline 3 & $\mathrm{R} 4$ & Kondisi perputaran angka meter gas sesuai dengan jumlah pemakaian & I \\
\hline 4 & R5 & Kehandalan material yang digunakan pada jaringan meter gas rumah tangga & I \\
\hline 5 & R6 & Kecepatan petugas melayani keluhan sesuai dengan waktu yang dijanjikan & I \\
\hline 6 & $\mathrm{R} 7$ & Permohonan keluhan pelanggan direspon dengan positif & I \\
\hline 7 & R9 & Kecepatan tanggapan dalam melayani permohonan pemasangan meter gas baru & I \\
\hline 8 & R3 & Keandalan stabilitas jaringan meter gas & II \\
\hline 9 & $\mathrm{R} 8$ & Memberikan konsultasi langsung kepada pelanggan & II \\
\hline 10 & A11 & Perbaikan dan pemasangan meter gas dilakukan dengan baik dan aman & II \\
\hline 11 & E16 & Kemudahan dalam menhubungi customer service & III \\
\hline 12 & E17 & Selalu menunjukkan sikap bersedia dan ingin membantu pelanggan & III \\
\hline 13 & E18 & $\begin{array}{l}\text { Adanya penjelasan dan sosialisasi instruksi penggunaan jaringan meter gas } \\
\text { rumah tangga }\end{array}$ & III \\
\hline 14 & T19 & Pakaian petugas rapi & III \\
\hline 15 & $\mathrm{~T} 20$ & $\begin{array}{l}\text { Kuitansi/surat rekening sebagai bukti pembayaran selalu diberikan kepada } \\
\text { pelanggan }\end{array}$ & III \\
\hline 16 & $\mathrm{~T} 21$ & Meter gas menggunakan peralatan modern & III \\
\hline 17 & $\mathrm{~T} 22$ & Tempat pembayaran yang nyaman & III \\
\hline 18 & A10 & Karyawan PT. Jabar Energi selalu bersikap ramah dan sopan & IV \\
\hline 19 & A12 & Kelancaran dalam proses pembayaran di tempat pembayaran gas & IV \\
\hline 20 & A13 & Keamanan dalam melakukan perbaikan dan pemasangan alat jaringan gas meter & IV \\
\hline 21 & E14 & Pelayanan terhadap pelanggan tidak membedakan status sosial & IV \\
\hline 22 & E15 & Pertanyaan pelanggan selalu dijawan dengan baik & IV \\
\hline
\end{tabular}


Tabel 10. Prioritas Perbaikan

\begin{tabular}{|c|c|c|c|}
\hline Prioritas & Variabel & Identifikasi Masalah & Tindakan \\
\hline 1 & $\begin{array}{l}\text { Kecepatan petugas } \\
\text { melayani gangguan } \\
\text { kesalahan rekening } \\
\text { meter (R9) }\end{array}$ & $\begin{array}{l}\text { - Menunggu hasil cek meter } \\
\text { lapangan } \\
\text { - Menunggu hasil dari data base } \\
\text { rekening pelanggan }\end{array}$ & $\begin{array}{l}\text { - Training peningkatan kemampuan } \\
\text { tentang meter gas } \\
\text { - Memberikan keterikatan dan } \\
\text { kepercayaan kepada pelanggan (berupa } \\
\text { pemberian detail form rekening) } \\
\text { - Mempermudah registrasi keluhan } \\
\text { pelanggan }\end{array}$ \\
\hline 2 & $\begin{array}{l}\text { Kecepatan petugas } \\
\text { melayani keluhan } \\
\text { sesuai dengan waktu } \\
\text { yang dijanjikan (R6) }\end{array}$ & $\begin{array}{l}\text { - Kurangnya koodinasi antar } \\
\text { karyawan } \\
\text { - Penjadwalan keluhan pelanggan } \\
\text { tidak tersusun rapi } \\
\text { - Keterbatasan teknisi ahli }\end{array}$ & $\begin{array}{l}\text { - Membuat SOP penanganan keluhan } \\
\text { pelanggan } \\
\text { - Training peningkatan kemampuan } \\
\text { keluham gas bagi karyawan } \\
\text { - Mensosialisasikan teknologi meter gas } \\
\text { kepada pelanggan } \\
\end{array}$ \\
\hline 3 & $\begin{array}{l}\text { Kehandalan material } \\
\text { yang digunakan pada } \\
\text { jaringan meter gas } \\
\text { rumah tangga (R5) } \\
\end{array}$ & $\begin{array}{l}\text { - Gas kotor/terdapat condensat } \\
\text { - Pembukaan kran/valve yang } \\
\text { secara tiba-tiba } \\
\text { - Intalasi yang tidak sesuai standar } \\
\end{array}$ & $\begin{array}{l}\text { - Mensosialisasikan penggunaan meter } \\
\text { gas yang benar kepada pelanggan } \\
\text { - Pengecekan dan perbaikan jaringan } \\
\text { secara berkala }\end{array}$ \\
\hline 4 & $\begin{array}{l}\text { Kondisi perputaran } \\
\text { angka meter gas } \\
\text { sesuai dengan jumlah } \\
\text { pemakaian (R4) }\end{array}$ & $\begin{array}{l}\text { - Terjadi aliran balik gas } \\
\text { - Terjadi kebocoran pada jaringan } \\
\text { gas } \\
\text { - Pembukaan penutupan kran/valve } \\
\text { secara tiba-tiba }\end{array}$ & $\begin{array}{l}\text { - Melakukan kalibrasi meteran } \\
\text { - Training peningkatan kemampuan } \\
\text { karyawan } \\
\text { - Mensosialisasikan penggunaan meter } \\
\text { gas yang benar kepada pelanggan } \\
\end{array}$ \\
\hline 5 & $\begin{array}{l}\text { Keakuratan catatan } \\
\text { yang dilakukan } \\
\text { petugas pencatan } \\
\text { meter gas (R1) }\end{array}$ & $\begin{array}{l}\text { - Kurang teliti dalam penulisan } \\
\text { meter gas oleh karyawan } \\
\text { pencatan meter } \\
\text { - Kurang mengetahui cara } \\
\text { membaca meter gas } \\
\end{array}$ & $\begin{array}{l}\text { - Training peningkatan kemampuan } \\
\text { petugas pencatat meter gas } \\
\text { - Memberikan simbol pada meter gas } \\
\text { untuk mempermudah pencatat meter } \\
\text { gas }\end{array}$ \\
\hline
\end{tabular}

\section{KESIMPULAN}

Adapun kesimpulan dalam penelitian ini yaitu kualitas layanan pengelola dalam mendistribusikan gas bumi ke konsumen dilihat dari 5 dimensi yaitu Reliability, Responsive, Assurance, Emphaty, Tangibles tidak ada yang lebih dari 80\% kecuali dimensi Emphaty mempunyai nilai tingkat harapan dan kinerja mencapai 90,88\% menunjukkan angka yang sangat baik. Tingkat kepuasan pelanggan jaringan gas bumi rumah tangga pada saat ini masih rendah, kinerja pengelola jaringan gas bumi saat ini dinilai masih jauh dari harapan pelanggan sehingga pelangga merasa tidak puas. Terdapat 5 variabel yang menjadi prioritas perbaikan berdasarkan analisis IPA (Importance Performance Analysis) dan prioritas utama perbaikan yaitu kecepatan petugas melayani gangguan kesalahan rekening meter, kecepatan petugas melayani keluhan sesuai dengan waktu yang dijanjikan, kehandalan material yang digunakan pada jaringan meter gas rumah tangga, kondisi perputaran angka meter gas sesuai dengan jumlah pemakaian, keakuratan catatan yang dilakukan petugas pencatan meter gas.

\section{DAFTAR PUSTAKA}

[1]. Evan \& Lindsay, 2005,The management and Control of Quality, Singapore: Thomson.

[2]. Parasuraman, Zeithaml, \& Berry, 1985, A Conceptual Model of Service Quality and its Implications for Future Research, Journal of Marketing, 49, 41-50.

[3]. Parasuraman, Zeithaml, \& Berry, 1988, SERVQUAL A Multiple-Item Scale for Measuring Consumer Perception of Service Quality. Journal of Retailing, 64,1-12.

[4]. Gronroos's., 2004, Service Quality Dimensions an examination of Gronroos's Service Quality Model, Emerald Group, 14,266-277. 